\title{
Erschließung der Erfahrung von Frauen und die Entdeckung neuer theologischer Kategegorien
}

\author{
Stephanie Klein ${ }^{1}$ \\ Universität des Saarlandes (Saarbrücken, Germany) \\ Research associate: University of Pretoria
}

\begin{abstract}
Unlocking women's experience and discovering new theological categories

One of the most central issues in a feminist practical theology is that of the experience of women. This issue raises the questions of how this experience can be accessed and in what manner ways or methods can be found by means of which women's experience can be adequately articulated. Without such articulation, reflection on women's experience would not be possible. This article indicates the theological meaning of an adequate recollection and articulation of women's experiences. It discusses the work of the North-American theologian, Nelle Morton whose method of hearing to speech has opened up a safe space for women in which to recall and recount their experiences. The article concludes that hearing to speech as a method for unlocking women's experience can be useful to the feminist theological discus-sion. It also indicates how reflection on the specific experiences of women can contribute to theological insight and theories. Another ver-sion of this article was published in Meyer-Wilmes, $H$, Troch, $L$ \& Bons-Storm, $R$ (eds) 1998, Feminist perspectives in Pastoral Theology, 47-71. Mainz: Grünewald, Leuven: Peeters (Yearbook of the European Society of Women in Theological Research 6.)
\end{abstract}

\section{EINLEITUNG}

Feministische Theologie erwächst aus den Erfahrungen und dem Glauben von Frauen und bleibt auf diese bezogen. Doch Erfahrungen von Frauen sind sehr unterschiedlich, sie können gegensätzlich sein, "die" (eine) Erfahrung von Frauen

\footnotetext{
${ }^{1}$ Dr Stephanie Klein is Assistant Professor at the Department of Practical Theology and Ethics at the Universität des Saarlandes in Saarbrücken and at the Gutenberg-University in Mainz, Germany. Dr Klein participates as research associate in the research project "Pastoral Care with Women", directed by Prof Dr Yolanda Dreyer, Department of Practical Theology, University of Pretoria. This project is supported by the Research Development Programme of the University of Pretoria.
} 
gibt es nicht. Selbst innerhalb einer Biographie sind Erfahrungen oft diffus und widersprüchlich. Manche Erfahrungen sind den Frauen selbst gar nicht ohne weiteres zugänglich. Hinzu kommt, dass innen keine Sprache zur Verfügung steht, sie adäquat zu artikulieren, denn die Androzentrik der Sprache führt bereits in dem Moment zu Verzerrungen, in dem eigene Erfahrungen denkend erinnert und sprachlich artikuliert werden wollen.

Die Frage nach den Erfahrungen von Frauen, die Suche nach Wegen oder Methoden eines angemessenen Zugangs zu ihnen und nach Möglichkeiten, sie adäquat zur Sprache zu bringen, um sie der Reflexion zugänglich zu machen, dürfte zu den zentralen Problemstellungen einer feministischen Praktischen Theologie gehören. Diese Fragen können nicht rein theoretisch gelöst werden, sondern nur im Bezug auf die Praxis von Frauen. Frauen haben in Frauengruppen, Selbsterfahrungsgruppen, Selbsthilfegruppen oder in persönlichen Beziehungen untereinander schon lange begonnen, sich auf die Suche nach ihren Erfahrungen und einer adäquaten Artikulation zu machen (vgl Libreria delle donne di Milano 1989).

Im folgenden möchte ich versuchen, die existentielle und theologische Bedeutung der adäquaten Erinnerung und Artikulation von Erfahrungen von Frauen aufzuzeigen und der Spur der amerikanischen Theologin Nelle Morton folgen, die in der Praxis des hearing to speech von Frauen einen Weg entdeckt hat, in dem Frauen sich gegenseitig den Raum einer adäquaten Erinnerung und Erzählung von eigenen Erfahrungen eröffnen. Das hearing to speech könnte als eine Methode der Erschließung von Erfahrungen von Frauen für die feministischtheologische Diskussion richtungsweisend sein. Hier zeigt sich auch, wie die theologische Reflexion der eigenen Erfahrungen der Frauen die theologischen Erkenntnisse, Kategorien und Theorien verändert (Klein 1997:283-297).

\section{DIE BEDEUTUNG VON ERINNERN UND ERZÄHLEN ALS KATEGORIEN DER VERGEWISSERUNG UND RETTUNG VON IDENTITÄT}

Das Erinnern und Erzählen eigener Erfahrungen, ganz besonders, wenn es bedrängende Erfahrungen wie Bedrohung, Leiden oder Schuld sind, gehören zur Selbst- und Identitätsvergewisserung von Frauen und Männern. Seelsorge und Therapien wissen schon lange um den heil- und identitätsstiftenden Charakter 
des oft mühsamen und schmerzhaften Erinnerns und Erzählens eigener Leidenserfahrungen. Wo Erinnerung und deren Erzählung behindert oder zerstört wird, da wird Identität, da wird die freie Entfaltung des Subjekts verhindert oder zerstört. Wir wissen dies z B von Missbrauchserfahrungen von Mädchen oder Jungen. Oft ist es sehr schwierig für die betroffenen Kinder, davon zu reden, und wenn sie es tun, wird es häufig angezweifelt, hinterfragt, ignoriert oder einfach nicht geglaubt, so dass sie selbst schließlich an dem Wahrheitsgehalt ihrer Erfahrung zweifeln. Oft werden solche Erlebnisse verdrängt, aber gerade dadurch bestimmen sie ein Leben lang die Gefühle, Erfahrungen und Handlungen. Sie kehren wieder als Ängste, als Depressionen, als Vermeidungsstrategien, als Wiederholungshandeln etc. Erinnern und Erzählen hilft und befreit, denn es schafft neues Selbstbewusstsein, neue Identität und Handlungsfähigkeit. Das Erzählen macht einen wesentlichen Teil des seelsorglichen Geschehens aus. Heinz Streib (vgl 1996:339-359) bezeichnet Seelsorge deshalb direkt als "heilsames Erzählen". Sie ist "Praxis heilsamen Erzählens, indem Menschen erinnernd und erzählend ihre Biographie annehmen und sich dabei auf eigene und fremde Erzählungen beziehen" (Streib 1996:343).

Erinnern und Erzählen sind jedoch mehr als eine therapeutische Methode. Johann Baptist Metz (1977) bezeichnete sie als Kategorien der Rettung des Subjekts und als solche als fundamentale Kategorien der Theologie. Sie bestimmen die Grundstruktur des christlichen Glaubens. Denn Gott des Lebens, der Erlösung und Befreiung bewahrheitet sich dort, wo auf ihn/sie gehofft wird, wo er/sie als befreiend erfahren wird. Diese Erfahrungen drängen dazu, erinnert und weitererzählt zu werden.

Das Erzählen ist die Sprachform, die das Erlebte am unmittelbarsten ausdrückt. Dabei ist nicht an eine runde, schöne Geschichte zu denken, wie sie sich erst im häufigen Wiedererzählen herausbildet. Eher im Gegenteil: das unmittelbare, unverarbeitete Erleben drückt sich gerade im Stammeln aus, es wird gerade nicht schlüssig sein, sondern fragmentarisch, diffus, vielleicht verzerrt, paradox oder symbolisch (vgl Klein 1994:27-30, 112-123)². Erzählen

\footnotetext{
${ }^{2}$ Je betroffener eine Person von dem Erlebten ist, desto diffuser wird die sprachliche Artikulation sein; es gibt Erlebtes, von dem über lange Zeit überhaupt nicht gesprochen werden kann. Zur sprachlichen Artikulation von Erinnerung und Erfahrung vgl Klein (1994:27-30, 112-123).
} 
weist über sich selbst hinaus und ist gerade darin auch die Sprache des Religiösen, die versucht, das Unsagbare zu sagen (vgl Weinrich 1973:329-334; Metz 1973:334-341; Kaempfert 1983). Dieses Erzählen ist auch die Sprachform, in der einer diffusen Hoffnung Ausdruck gegeben, in der Neues und nie Dagewesenes artikuliert werden kann. Es ist die Sprache, in der eine Zukunft antizipiert werden kann, die nicht eine Verlängerung des Gewesenen ist, sondern das Moment des Neuen, nie Dagewesenen in sich trägt (vgl Metz 1977:183).

Das Erinnern und Erzählen ist politisch und "gefährlich".

Zerstörung von Erinnerung erweist sich als systematische Verhinderung von Identität ... Die Entwurzelung der Sklaven, ihre Deportation diente allemal der Zerstörung ihrer Erinnerungen und gerade darin der erfolgreichen Befestigung ihres Sklavendaseins, ihrer systematischen Verohnmächtigung im Interesse der völligen Unterwerfung. Andererseits beginnt die Bildung von Identität in der Erweckung von Erinnerungen

(Metz 1977:63)

Aus der Erinnerung an die Leiden und Widerstände ziehen Frauen und Männer neue Identität. "Die Erinnerung gilt hier allemal als Kategorie der geschichtlichen Identitätsfindung, als Kategorie der Befreiung" (Metz 1977:64).

Erinnern und Erzählen ermöglicht die Solidarisierung und wird zur Anfechtung der sich als totalitär und universal gebenden Gegenwart. Das Erinnern an Leiden und erfahrene Gewalt, an verweigerte Lebensmöglichkeiten, an uneingelöste Hoffnungen und Sehnsüchte entlarvt die Geschlossenheit der geltenden Maßstäbe, Normen, Wirklichkeitskonstruktionen und Sprachmuster als identitätszerstörend. "Solche Erinnerung durchstößt den Bann des herrschenden Bewußtseins. Sie reklamiert unausgetragene, verdrängte Konflikte und unabgegoltene Hoffnungen. Sie hält gegen die herrschenden Einsichten früher gemachte Erfahrungen hoch und entsichert damit die Selbstverständlichkeiten der Gegenwart" (Metz 1977:176).

Diese Überlegungen zur Bedeutung von Erinnern und Erzählen bleiben freilich ohne die Einführung der Kategorie der Geschlechterdifferenz in ihrer scheinbaren Allgemeinheit einer androzentrischen Perspektive verhaftet. Sie 
gewinnen eine eigene Brisanz, wenn sie aus der Perspektive und von der Situation von Frauen her gedacht werden. So gehört bereits die Vorstellung, Frauen könnten ebenso wie Männer einfach über ihre Erfahrungen sprechen, zum System ihrer Entfremdung. In der Perspektive von Frauen wird aber auch eine unsichtbare Seite sichtbar, die durch die Fokussierung auf das Erzählen in der Bedeutungslosigkeit verschwand: das Hören. Für die Befreiung von Frauen hat es einen zentralen Stellenwert, eine Schlüsselfunktion zu ihrem eigenen adäquaten Erinnern und Erzählen und damit zu ihrer Identität.

\section{DIE UNSICHTBARE SEITE: DAS HÖREN}

Jedes Erzählen ist ein Beziehungsgeschehen; zu jedem Erzählen gehört das Hören. Niemand erzählt ohne ein Gegenüber, das ihn oder sie hört. Auch noch das Selbstgespräch, der innere Dialog, die autobiographischen Notizen oder das Tagebuch brauchen ein Gegenüber, sei es eine sich in Erinnerung gerufene konkrete Person, das verinnerlichte "öffentliche Forum" (Luther 1987:71) oder ein "fiktiver anderer" (Luther 1987:73). Doch für zentrale, beunruhigende Erfahrungen genügt dies nicht: gerade in der Seelsorge wird häufig erfahren, wie erlösend es für viele Frauen und Männer ist, wenn sie, oft nach vielen Jahren, zum ersten Mal eine Person finden, die ihnen zuhört, der sie ihre Leidensgeschichte oder Schuldgeschichte erzählen können. Das Befreiende und Identitätsstiftende ist nicht allein das Erzählen, sondern vor allem die Tatsache, dass hier erstmals im Leben jemand in einer Weise zuhört, die das Erzählen erst ermöglicht.

In der theologischen Reflexion hat das Hören kaum einen eigenen Stellenwert. Es wird unter das Erzählen subsumiert. Wo von Hören die Rede ist, kommt es als das Hören des Wortes Gottes (vgl Knauer 1983) oder als Gehorchen vor. Es geht in systematisch-theologischen Abhandlungen um das "Wort Gottes", das im und durch den Glauben erfasst und in "sachgemäßer" Weise verkündigt werden soll. In vielen sprachwissenschaftlich und pragmatisch beeinflussten Abhandlungen geht es um die Wirkung des Sprechens, das als Handeln gefasst ist: darum, dass das Gesprochene bei den Hörenden 
Betroffenheit auslöst, sie verändert, sie belehrt. Dahinter steht häufig ein Defizitmodell. Die hörende Person soll verändert werden, ihr wird etwas gegeben, was ihr fehlt, was aber die sprechende Person hat, mitteilt oder bewirken kann. In der Seelsorge, in der Tiefenpsychologie und der Gesprächstherapie wurde die Methode des Zuhörens aus der Erfahrung heraus entwickelt, dass Heilung nur möglich ist, wenn das Leid zur Sprache gebracht wird. Doch auch hier bleibt das Interesse auf das Erzählen gerichtet; das Hören ist keine eigene theoretische Kategorie, sondern eine Methode zum Erreichen eines bestimmten Zweckes.

\section{ERZÄHLEN UND HÖREN IN DER ERFAHRUNG VON FRAUEN}

Erzählen und Hören kommen im Leben von Frauen anders vor als im Leben von Männern. Frauen erfahren sich häufig als Schweigende oder zum Schweigen Gebrachte und erfahren Sprechen häufig als Gewalt (vgl Trömel-Plötz 1984; Belenky 1989:92). Wenn Frauen sprechen, wird ihnen nicht so aufmerksam zugehört wie Männern, sie werden häufiger unterbrochen, ihnen wird weniger Redezeit zugestanden, ihre Beiträge werden häufig ignoriert oder lächerlich gemacht (Trömel-Plötz 1982, 1992). Viele Mädchen werden phasenweise oder über einen längeren Zeitraum sehr still, sie verstummen, vertrauen sich höchstens einer Freundin oder ihrem Tagebuch an (vgl Brown \& Gilligan 1994). Doch auch als erwachsene Frauen finden sie sich häufig auf der Seite derer, die zuhören, nachfragen, schweigen, ihre Kinder, Männer, Freunde, Klienten zum Erzählen ermuntern. In der Öffentlichkeit, im Berufsleben, in der Kirche sind sie seit Jahrhunderten kaum auf der Seite derer, die "das Sagen haben", die entscheiden und die Wirklichkeit definieren, sondern überwiegend auf der Seite derer, denen gesagt wird, was sie zu tun, zu denken, zu glauben haben. Die Erfahrung des Schweigens oder die, keine Stimme zu haben, gehört so sehr zu ihrer Lebenswelt, dass Schweigen, Zuhören oder Keine-Stimme-Haben häufig die Metaphern geworden sind, in denen Frauen ihr Leben beschreiben (vgl Belenky et al 1989:31; Brown \& Gilligan 1994). 
Für Frauen besteht das besondere Problem aber nicht nur darin, dass sie eher mit der Seite des Zuhörens, Gehorchens oder Schweigens vertraut sind, sondern vor allem darin, dass innen zur Artikulation ihrer eigenen Erfahrung keine adäquate Sprache und Symbolwelt zur Verfügung steht. In der Sprache schlägt sich die Perspektive, Erfahrungswelt und Symbolwelt von Männern nieder (vgl Trömel-Plötz 1982, 1984, 1993; Pusch 1984, 1990; Schüssler Fiorenza1985:387-398). Frauen werden subsumiert und - oft, aber nicht immer mitgemeint. Diese Sprache entfremdet Frauen von ihren eigenen Erfahrungen und führt schon im Ansatz, wo Erfahrung befreiend artikuliert werden will, zu Nicht-Identität. Da Frauen in die androzentrische Kultur hineingeboren und sozialisiert werden und diese selbst völlig verinnerlicht haben, bedarf es eines längeren Prozesses, um diese Zusammenhänge zu erkennen und kritisch zu reflektieren. Nelle Morton (1985:19-20) beschreibt einen solchen Bewusstwerdungsprozess so:

The prevalence of male terminology in the common speech appeared insignificant and even funny at first. Everybody knew that everybody did not mean literally male and that was that. Then there came a time when it ceased to be funny. Women began hearing themselves shut out of their own traditions; alienated from church, synagogue, and other religious groups .... As women questioned the generic use of male words, they were put down repeatedly with ridicule. Finally it became quite evident to them that male and not the generic in the male terminology was meant. Once women began to be aware of what language had done to them as little girls and was now doing to their own little girls, they experienced as dehumanising the pervasive male character of the entire language system .... There is no longer doubt in the minds of liberated women that the common speech of the American people presents an image of male control in pulpit, politics, education, industry, and family. It has become obvious that this language of the people reflects their own history, their world view, their understanding of one another, and the value placed on their lives together. It has become clear, also, how the language itself perpetuates and even creates for children a view of humanity in which women are considered of minor importance in shaping history and participating in politics. 


\section{FRAUEN OHNE SPRACHE - FRAUEN OHNE SELBSTBE- "STIMMTE" EXISTENZ}

Die Sprachlosigkeit von Frauen ist ein Phänomen, das auf die viel grundsätzlichere Situation der vom Mann abgeleiteten Existenz der Frauen hinweist. Diese Zusammenhänge hat die italienische Philosophin Adriana Cavarero (1993:65-102) in ihrem Aufsatz "Ansätze zu einer Theorie der Geschlechterdifferenz" stringent durchdacht. Ihr Gedankengang dürfte für das Verständnis und die Suche nach den Erfahrungen von Frauen erhellend sein.

Cavarero zeigt an der italienischen Sprache auf, dass der scheinbar neutrale Begriff des Menschen die Universalisierung des Männlichen in sich trägt. Der Mann erkennt sich als das Besondere seiner Universalisierung wieder, in diesem Prozess ist das Weibliche abwesend. Das universale Denken und Sprechen ist sein Denken und Sprechen.

Für die Frau gibt es diese Universalisierung ihres eigenen Seins nicht, und sie erkennt sich auch nicht im Universalen wieder. Sie erkennt sich (oder wird erkannt) als Gegenüber des Mannes, sie ist dessen "andere". Sie ist "das allgemeine Neutrum Mensch minus männlichem Geschlecht, das den wirklichen Inhalt und den wahren Ursprung dieser Universalisierung darstellt" (Cavarero 1993:71). Sie ist ein Mensch mit dem Zusatz des weiblichen Geschlechts, der kein "mehr" bedeutet, sondern ein Defizit.

Für die Frau folgt daraus, daß sie sich im Denken und in der Sprache eines universalen Subjekts, das sie nicht umfaßt, ja sogar ausgrenzt, ohne dafür Verantwortung zu übernehmen, nicht erkennen kann. In seinem Anspruch, auch für das ausgegrenzte Geschlecht zu gelten, löscht dieses Universale den logischen Abstand des ursprünglichen Verschieden-Seins aus, das zu einem abgeleiteten Verschieden-Sein eingeebnet wird.

(Cavarero 1993:71)

Es können nun zwei Weisen der Differenz der Frau unterschieden werden: einmal eine Differenz, die aus der Universalisierung des Männlichen als sekundäre Differenzierung hervorgeht. Diese sekundäre Differenz ist den Frauen aus der Sicht des Männlichen als unterscheidend zugewiesen. Zum anderen 
aber eine primäre Differenz, die sich aus der Tatsache ergibt, dass "der Mensch" nur als Frauen und Männer vorkommt, also immer "zwei ist". Folglich müsste neben die Selbst-Universalisierung des Mannes und seiner Erfahrungswelt auch in einer primären Differenz eine Selbst-Universalisierung der Frau treten; beide könnten sich nur noch in Anwesenheit des anderen Geschlechtes als Universales denken. Die Differenz zwischen Mann und Frau gehört dann zum universalen Menschen wesenhaft dazu.

Erst wenn sich die Frau nicht mehr über das männliche Universale als sekundäre Differenz bestimmt, sondern sich als eine ursprüngliche, primäre Differenz begreift, öffnen sich ihr Wege, zu einem eigenen Denken und zu einer eigenen Sprache und damit zu einer eigenen Subjekthaftigkeit, zu einer eigenen Selbsttranszendierung zu gelangen. Die Frau hat jedoch keine eigene Sprache, um ihr Erleben, ihre Erfahrungen zu sagen, sondern benützt von Anbeginn an die Sprache des anderen. "Sie stellt nicht sich selbst in der Sprache dar, sondern übernimmt mit dieser die Darstellungen, die der Mann von ihr produziert hat. Auf diese Weise spricht und denkt die Frau, sagt sich und denkt sich, aber nicht von sich selber ausgehend." (Cavarero 1993:75).

Wie aber kann die Frau zu einer Sprache finden, die von ihr selbst ausgeht? Wie kann sie sich selbst als ein Wesen erfassen, das nicht durch oder in Abgrenzung von dem Mann definiert ist, sondern ausgehend von dem eigenen Sein, von den eigenen Erfahrungen? Wenn auch die Sprache die ursprüngliche Geschlechterdifferenz auslöscht und der Frau eine sekundäre, abgeleitete zuweist, so kann sie doch nicht über das einfache Dasein eines ganzen, individuellen Subjekts hinwegtäuschen.

Das Wesen, das wir suchen, ist also das geschichtliche Wesen eines realen Subjekts, das sich ausgehend von sich selbst verstehen will. Dieses Bemühen um Selbstverständnis hat einen aktiven Aspekt, der mit der Entscheidung der Frau zusammenhängt, gerade die Darstellung des eigenen Subjekt-Seins zu produzieren, aber es hat auch einen sozusagen passiven Aspekt, der in dem Vertrauen besteht, auf sich selbst zu hören und den Wert nicht in Darstellungen zu suchen, die in einer ihr fremden Sprache "gelten", sondern darin, sich anzunehmen als die, die sie ist und die die Last eines noch-nicht glücklichen Schicksals trägt. 
Auch wenn dies zunächst noch armselig erscheint, so ist dies besser "als das Nachäffen jener glänzenden Geschicke des männlichen Subjekts, das es über Jahrhunderte in die Dunkelheit verbannt hat, um sich von diesem Schatten zu nähren" (Cavarero 1993:83).

Es gibt einen unsagbaren "Rest" des Bewusstseins dieser primären Differenz, und in der Beziehung zu anderen Frauen kann dieser "Rest" erinnert werden. "In den Gesprächen unter Frauen kündigt dieser Begriff oft den Anbruch einer atemlosen und zugleich glücklichen sprachlichen Produktion an, das SichEntfalten einer Einbildungskraft, die für einen Augenblick den Wunsch nach Selbstdarstellung anregt und befriedigt" (Cavarero 1993:84).

\section{DIE ENTDECKUNG DES HEARING TO SPEECH IN DER ERFAHRUNG VON FRAUEN}

Die amerikanische Theologin Nelle Morton $(1985)^{3}$ hat nach Wegen gesucht, wie Frauen ihre eigenen Erfahrungen in einer eigenen Sprache zum Ausdruck bringen können. In der Praxis von Frauengruppen entdeckte sie schließlich eine bestimmte Art des Einander-Hörens, durch das sich Frauen gegenseitig den Raum zur Artikulation ihrer eigenen, oft verborgenen und verdrängten Erfahrungen eröffneten. Für diese Art des Hörens gab es bislang noch keinen Begriff, und es ist deshalb "unbegriffen" geblieben. Morton nannte es hearing to speech - Hören als Ermächtigung zum Sprechen. Durch diese Benennung wurde die Praxis sichtbar und reflektierbar. Im Nachdenken über ihre Praxis fanden Morton und die Frauen heraus, welche weitreichenden Auswirkungen sie für die theologische Reflexion hat. Sie begriffen das hearing to speech als eine fundamentale Kategorie der Befreiung von Frauen, die ein neues Erkennen Gottes, ein neues Verständnis von Theologie-Treiben und Theologie, von Verkündigung und Befreiung hervorbringt. Ihre Erfahrungen und theologischen

\footnotetext{
${ }^{3}$ Nelle Morton, geb. 1905 in Tennessee, studierte Theologie in New York und Genf, lehrte u a an der Theological School of Drew University, engagierte sich für Bürgerrechte, für Frieden und Menschenrechte, für die Frauenbefreiung sowie für soziale und kirchliche Reformen. Ihre jahrzehntelange Suche nach einer angemessenen Artikulation der Erfahrungen von Frauen und die theologischen Reflexionen ihrer Entdeckungen beschreibt sie am Ende ihres Lebens in dem bislang nicht übersetzten Buch The Journey is Home, Boston 1985.
} 
Reflexionen erzählt Morton in narrativ-biographischer Weise im Alter von fast 80 Jahren rückblickend in ihrem Buch The Journey is Home ${ }^{4}$.

Nelle Morton's Aufzeichnungen sollen hier exemplarisch als ein Weg für eine feministisch-theologische Erkenntnis- und Theoriegenerierung aus der Praxis und den Erfahrungen von Frauen angeführt werden, der für die praktischtheologische Frage nach diesen Erfahrungen und den Methoden ihrer Erschließung richtungsweisend sein könnte. Im folgenden möchte ich zunächst von der Entdeckung des hearing to speech erzählen und dann aufzeigen, wie aus dieser zentralen und befreienden Erfahrung von Frauen neue theologische Erkenntnisweisen hervorgehen.

Morton erzählt von einem Schlüsselerlebnis, durch das ihr die Bedeutung des Hörens aufging. In einer kleinen Gruppe von Frauen beginnt eine sehr stille und fast furchtsame Frau gegen Ende eines Workshops zögernd Teile ihres Lebens zusammenzutragen. Dieses Erzählen der eigenen Erfahrungen ist körperlich schmerzhaft, ohne daß sie die Möglichkeit hat, dem einen angemessen Ausdruck zu geben: “It hurt', she began. 'It hurt all over'. She touched herself in various places before she added, 'but I don't know where to begin to cry. I don't know how to cry."' (Morton 1985:205; vgl auch 1985:127). Während sie ihre leidvolle Geschichte erzählt, hören alle zu. "When she reached a point of the most excruciating pain, no one moved. No one interrupted her. No one rushed to comfort her. No one cut her experience short. We simply sat. We sat in a powerful silence" (Morton 1985:205). Als sie die Erzählung beendet hat, wendet sie sich an die Zuhörerinnen: "'You heard me. You heard me all the way ... I have a strange feeling you heard me before I started. You heard me to my own story. You heard me to my own speech'" (Morton 1985:205).

Morton ordnet diese Erfahrung zunächst als eine singuläre ein, doch als sie sich in kleinen Gruppen von Frauen immer neu wiederholt, beginnt sie darin

\footnotetext{
${ }^{4}$ Das Buch enthält in der Reihenfolge ihrer Entstehung Essays, die Morton zwischen ihrem fünfundsechzigsten und neunundsiebzigsten Lebensjahr geschrieben hat. Jedes Essay ist eingeleitet durch die Beschreibung des Kontextes, in dem es entstanden ist. Auf diese Weise legt sie nicht nur ihre Erkenntnisse und Reflexionen dar, sondern dokumentiert auch ihren eigenen biographischen Erkenntnisprozess - eine beeindruckende Weise biographisch-kontextueller Theologie.
} 
ein allgemeineres Phänomen der Bewusstwerdung von Erfahrungen von Frauen zu erkennen. Sie beschreibt dieses Bewusstwerden als einen Prozess, der ausgehend von einer Verteidigungshaltung langsam in die Abgründe des eigenen Seins führt und eine verborgene Verzweiflung zum Vorschein bringt (vgl Morton 1985:14):

The first indication of a stirring consciousness appears to be defensiveness. Since women find it difficult to admit they are searching for liberation perhaps they are not even aware of the need. Women seem to go to great length to make clear to other women that even thougt life may be tough on them at times, in the long run all is well. They have been conditioned to be loyal at all costs to father, husband, children, boss, and colleagues. Irrelevant claims are exchanged: 'I love my husband.' 'It is my choice to keep house.' 'I have never really known discrimination. I have learned how to get along with my boss.' Some women need help. For them there should be equal pay for equal work.' Round after round of defense finally winds down to a vague hurt - a diffused hurt that most often cannot be isolated or located. As a woman seeks to get in touch with the pain, she begins to admit a sense of boredom, of being caught and trapped. Broken articulation opens up more of the same hurt until it finally focuses to a point of despair. The hurt becomes intolerable.

Die Erfahrung, von den anderen Frauen zum eigenen Sprechen gehört zu werden, leitet einen neuen Prozess ein. Die Frauen beginnen, sich und andere neu wahrzunehmen und neu zu hören. Diese Entdeckungen machen innen Freude und tragen zum Aufbau einer neuen Identität bei. "They began to appropriate a new kind of courage to explore the future with no known history to inform and a new ability to articulate that which has never before come to speech. They began to know themselves as persons of worth who would pick up their own lives and be responsible for them" (Morton 1985:18).

Experiences such as these have brought women to a new joy when they discover themselves and others for the first time; and to renewed conviction that it is no longer appropriate to allow men to define their lives and to do their theological thinking even though the men are the women's won pastors or their own professors; nor is it any longer 
appropriate to allow men to provide their identity even though the men are their own fathers, husbands, their bosses, their colleagues, or the leaders of their community. These women have come to see that the gift of themselves is precious, sacred, with unique potential.

\section{ASPEKTE DES HEARING TO SPEECH}

Das hearing to speech ist eine Praxis und ein befreiendes Erleben von Frauen; es ist bislang unbenannt und unsichtbar gewesen. Es fällt Morton schwer, es genauer zu beschreiben. "Since this kind of hearing first came to me, I have tried to analyze the process, but it resists analysis and explanation. It traffics in another and different logic. It appears to belong in woman experience" (Morton 1985:128). Um das hearing to speech näher zu charakterisieren, möchte ich einige Aspekte zusammenfassen, die Morton an verschiedenen Stellen ihres Buches beschreibt oder reflektiert. Ergänzend möchte ich aber auch eine Brücke schlagen zu den eingangs dargestellten theologischen Überlegungen zu den Kategorien Erinnern und Erzählen.

- $\quad$ Das Hören geht dem Sprechen voraus. Es schafft Vertrauen und den Raum, in dem das Aussprechen der eigenen Erfahrungen, besonders der gut behüteten Verletzungen, erst möglich wird. Es ist die Bedingung der Möglichkeit eines solchen Sprechens. "It is questionable that any of the women had arrived at a sense of trust before they began to tell their stories to one another. Perhaps the nearer truth is that trust came because they were heard and not the other way around" (Morton 1985:17). Damit aber wird die Logik des Sender-EmpfängerModells umgekehrt. Das Hören ist nicht als Reaktion auf das Sprechen zu verstehen, sondern das Sprechen als Reaktion auf das Hören. "Hearing became an act of receiving the woman as well as the words she was speaking" (Morton 1985:17). Eine vollständige Umkehrung der bestehenden Logik, "A complete reversal of the going logic ... a depth hearing that takes place before the speaking - a hearing that is far more than acute listening" (Morton 1985:127128).

- Das Hören ist ein Akt der ganzen Person, ihres Bewusstseins, ihrer Sinne, ihrer Seele und ihres Körpers. "Learning to listen with one's whole body. Learning to hear with the eye and see with the ear and speak with the hearing" (Morton 1985:83). "A hearing engaged in by the whole body that evokes speech - a new speech - a new creation" (Morton 1985:127). Es ist ein voraussetzungsloses 
Annehmen der anderen Frau und ihrer Worte. "Women came to new speech simply because they were being heard. Hearing became an act of receiving the woman as well as the words she was speaking" (Morton 1985:17). Dieses Hören bewertet, urteilt und kritisiert nicht. "All women's experiences are valid data and must be respected" (Morton 1985:126). Das bedeutet nicht, dass die Hörende sich mit der Sprecherin identifizieren oder mit allem übereinstimmen muss: "She may be wrong. She may be sick. She may be confused. She did not have to be agreed with but she had to be heard" (Morton 1985:18). Ein solches Hören repräsentiert nicht das "öffentliche Forum", eine Norm, ein Prinzip oder einen Maßstab, die sich im Bewusstsein der Sprecherin schon vor dem Formulieren als Kontrollinstanz niederschlagen, wie dies beim Zuhören häufig der Fall ist.

- $\quad$ Das Hören führt zu den eigenen verschütteten oder verdrängten Erfahrungen und ruft die authentische Artikulation dieser Erfahrungen hervor. "A hearing that is a direct transitive verb that evokes speech - new speech that has never been spoken before" (Morton 1985:205). Die Unmittelbarkeit der Erfahrung lässt neue Worte, neue Sprache entstehen, die das Erfahrene adäquat ausdrückt. Das Erfahrene muss nicht mehr entfremdet und verzerrt in der Sprache und dem Symbolsystem derer wiedergegeben werden, die dieses Leben entfremdet und verletzt haben.

Das annehmende Hören schafft den Raum, in dem Erinnerung unzensiert zugelassen und zum Ausdruck gebracht werden darf. Dies ist der Raum auch der "gefährlichen Erinnerung" und der "gefährlichen Erzählung" von Frauen: die Erinnerung an verdrängte Leiden, an verbotenen Groll und Hass, an Sehnsüchte nach dem Eigenen, nach dem, was die herrschende Kultur und ihre Rollenmuster als nicht angemessen ansehen und abwerten. Hier liegt der Ursprung des Aufbruchs zu etwas Unbekannten, für das es noch keine Formen, Symbole, keine Sprache gibt. Gefährlich ist diese Erinnerung für die altbekannten und bewährten Stützen der eigenen Person, gefährlich aber auch für gesellschaftliche Normen und Rollen, deren selbstverständliche Akzeptanz zerbricht und deren Charakter sich nun als unterdrückerisch entlarvt.

- $\quad$ Das Hören ist ein existentielles Beziehungs- und Begegnungsgeschehen zwischen Frauen, in dem sie sich gegenseitig ermöglichen, mit ihren eigenen Erfahrungen in Berührung zu kommen. In vielem, was die zum Sprechen Gehörte aus ihrer Erfahrung artikuliert, erkennen die Hörenden ihre eigenen vielleicht abgedrängten Erfahrungen. Die Unmittelbarkeit der Sprache rührt an das Innerste ihrer Existenz und öffnet innen den Weg, in Berührung mit den eigenen verschütteten Erfahrungen zu kommen und sich auch selbst zu hören. Auf diese Weise geschieht eine sehr unmittelbare existentielle Begegnung. "The speaker, stripped of every old prop, ... was able to go in all her agony directly to 
the other women present. In receiving the speaker (who had touched the quick of their own existence) the women heard the speaker speak for them to the extent that they, in turn, were able to receive themselves. They were able to relate to one another out of their whole selves rather than partially through the mind alone, or through the emotions alone" (Morton 1985:17).

\section{VON DER BEFREIENDEN ERFAHRUNG VON FRAUEN ZU EINER NEUEN THEOLOGIE}

Indem Nelle Morton die befreiende Erfahrung des hearing to speech unter den Frauen als eine Glaubenserfahrung begreift und theologisch reflektiert, gelangt sie zu einer neuen Theologie aus Erfahrungen von Frauen, einer feministischen Theologie. Diese macht Kritik an dem Anspruch der Universalität einer Theologie möglich, die sich nun als androzentrisch erweist.

\subsection{Neues Theologie-Treiben}

Nelle Morton begreift die befreiende Erfahrung des Hörens und Gehört-Werdens als eine religiöse Erfahrung, die Frauen zu einem neuen Theologie-Treiben führt. Dieses Theologie-Treiben erlangt Erkenntnis "aus dem tiefsten Abgrund des Seins" heraus, aus der ganzen Existenz, die den Körper der Frauen, ihren Verstand und Geist einschließt. Zugleich ist es aber auch ein Theologie-Treiben aus der gemeinsamen Erfahrung der Frauen heraus. "We begin to experience theologizing as a process - organic, communal, and holistic. Organic because it comes up out of the deepest abyss of our being - at the point of our deepest cleavage from the male. Organic, also, because body, mind, spirit come up as one. We have not come into this astounding new thing through our mind alone. We have lived it into our own existence" (Morton 1985:82). Dieser Prozess lässt Frauen in der Gemeinschaft zu eigenen theologischen Benennungen kommen. "A communal process of theologizing was experienced by many groups of women partly because no expertise was present to supply the proper word and no authority had been paid to keep them on the track, to tell them what they think and what they see and what they hear and where they must come out. Women were thrown back onto their own resources and on one another" (Morton 
1985:18). Dieser Prozess ist offen für das Wirken des Heiligen Geistes, der weniger von Experten oder einer hierarchischen Struktur erwartet als vielmehr "als Gemeinschaft" (Morton 1985:82) erfahren wird.

Der theologischen Erkenntnis gehen also nicht Worte Gottes voraus, die die Theologin empfängt, über die sie nachdenkt, die sie reformuliert, auslegt, verkündigt. Zweierlei scheint hier angezeigt: Gott hört die Theologin zur eigenen Sprache und ruft die theologischen Erkenntnisse aus deren geschichtlichen, sozio-kulturellen, körperlichen und spirituellen Existenz hervor; und die Theologin hört andere zu ihrer eigenen Sprache - und die anderen werden sie zur eigenen Sprache hören. In diesem Dialog gelangen sie dann zu neuer Erkenntnis und Rede von Gott. Dieses Hören und von Gott und den anderen Frauen zur eigenen Sprache Gehört-Werden ist ein kritisches Korrektiv zu einem selbstgewissen, rezitativen, sich über die körperlich-sozio-kulturelle Verfaßtheit hinwegsetzenden theologischen Reden. "That kind of hearing would be prior to the theologians' own words. It might even negate and ruffle their words and render them unable to speak until new words emerge" (Morton 1985:129).

\subsection{Neue Erkenntnis und Rede von Gott}

Aus der befreienden Erfahrung des zum Sprechen Gehört-Werdens heraus kommen die Frauen zu einer neuen Erkenntnis und Rede von Gott: Gott wird als der ermöglichende Urgrund dieses Hörens zu einem neuen authentischen befreiten Sein erfahren, begriffen und zur Sprache gebracht. Gott ist Ursprung der Befreiungserfahrung. Gott ist selbst Hörende/r, die/der die Frauen und Männer zu ihrer eigenen unverstellten Sprache und zu ihrem befreiten Sein hört. Gott redet nicht in erster Linie, Gott hört und schafft dadurch den Frauen und Männern den Raum, ihre eigene Sprache zu finden, die authentisch aus den eigenen Erfahrungen des Leidens und der Freuden aufsteigt, die sie nicht mehr entfremdet, sondern die den göttlichen Urgrund der Erfahrungen ausdrückt und sich als das wahrhaft Menschliche artikuliert. Genau dies ist Gottes Weise zu sprechen. "We experienced God, as Spirit, hearing human beings to speech - to new creation. The Word came as human word, the human expression to 
humanness. The creative act of the Spirit was not Word speaking, but hearing hearing the created one to speech" (Morton 1985:82).

Das "Sender-Botschaft-Empfänger-Modell" ist umgekehrt. Gott ist nicht "Sender" einer Botschaft, die die Menschen empfangen, um sie dann möglichst Wort-getreu an die "Hörer des Wortes" weiterzutragen, sondern Gott "empfängt" (receives) zuerst die Frauen und Männer, $\mathrm{d} h$ hört und nimmt sie an und ruft dadurch bei ihnen die "Botschaft" in der eigenen authentischen Sprache hervor sowie die Fähigkeit, andere zu hören und anzunehmen.

Die Wahrnehmung und Achtung der religiösen Erfahrung und theologischen Reflexion der Frauen lässt Morton zur Kritik an theologischen Konzepten gelangen, die allein das sprechende Subjekt und den sprechenden Gott in den Mittelpunkt ihrer Reflexionen stellen. Diese verlieren vor dem Erfahrungshintergrund der Frauen ihre Allgemeingültigkeit. In ihnen lässt sich nun die gesellschaftliche Erfahrung und Wirklichkeit von Männern entdecken: "Could the limiting imagery in the word Word - Logos - derive from a patriarchal way of perceiving and experiencing the universe? Would a more inclusive perceiving allow for persons to be heard into existence rather than spoken into existence? Could it be that Logos deified reduces communication to a one-way relationship - that of speak-ing - and bypasses the far more radical divine aspect of hearing?" (Morton 1985:54).

\subsection{Neue Verkündigung}

Dieses neue Verständnis von Gott hat Konsequenzen, wie Frauen zu anderen von Gott sprechen und Gott verkündigen können. Wenn Gott nicht in Worten zu den Menschen spricht, sondern die Worte durch ihr/sein Hören im Menschen hervorruft, dann heißt Verkündigung nicht zuerst das Erzählen der Botschaft, sondern zuallererst das vorbehaltlose Hören/Annehmen der anderen als Ermächtigung zu ihrer eigenen Sprache. Wo Menschen andere zum Ausdruck ihres befreiten Menschseins hören, da hören sie letztlich Gottes Wort zur Sprache. Verkündigung wäre dann nicht zuerst das Erzählen und Überzeugen, "not to deliver (to proclaim) the Word but to place her ear close to the pulse of the 
people" (Morton 1985:41), die Menschen zu ihrer eigenen Sprache zu hören und so das Wort Gottes aufsteigen zu lassen aus ihrer unverstellten und nichtentfremdeten Menschlichkeit. Dieses Hören ist bereits der Akt der Verkündigung, es ist ein "performatives" Hören, das den Inhalt der Verkündigung bereits geschehen lässt. Dass Gott der/die rettende und befreiende Gott ist, indem er/sie die Menschen zu befreitem Sein hört und annimmt, wird hier bereits vollzogen. Die Worte der Botschaft werden aus den befreiten Menschen hervorkommen.

Wenn der Rede von Gott das Hören als Ermächtigung zur eigenen Sprache vorausgeht, dann werden die Worte, in denen die Botschaft formuliert wird, aus dem Dialog zwischen Menschen erwachsen, die sich gegenseitig zu einer eigenen authentischen Sprache hören. Diese Überlegungen beinhalten die Kritik an einem Modell von Verkündigung, die von Heil redet, ohne der anderen Person auch nur die Gelegenheit zu geben, sich ihres Leidens und Unheils bewusst zu werden und es zu artikulieren, und die bereits in einem solchen Akt neues Unheil der Sprachlosigkeit, der verdrängten Leiden und der Entfremdung schafft.

\subsection{Neue Seelsorge}

Nelle Morton's Kategorie des hearing to speech eröffnet auch ein neues Verständnis von Seelsorge. Seelsorge könnte nun als ein heilendes Hören gefasst werden. Diese Art von Hören besagt, dass die andere jetzt nicht das Gerede der Seelsorgerin braucht, sondern zuallererst deren ganzes hörende/annehmende Dasein, das ihr ermöglicht, das Korsett der Rechtfertigungen Stück für Stück abzulegen, die Verletzungen zuzulassen und sie in eigener Artikulation zum Ausdruck zu bringen. Der eigentliche Akt der Seelsorge ist das "empfangende" Hören. Heilung wird möglich, weil die Frau in Berührung mit ihren eigenen Erinnerungen und Erfahrungen kommt, weil sie nach eigenen Worten für diese Erinnerung sucht und beginnt, in der gegenseitigen Beziehung unter Frauen sich in ihrer eigenen Würde als Frau zu begreifen, die keine sekundäre, von Mann abgeleitete oder zugestandene ist, sondern eine primäre. 
Die Frage, wie denn hier Gott ins Spiel kommt, erübrigt sich: die geheilte Frau wird den Urgrund ihrer Heilung selbst artikulieren; im Dialog werden beide, die sich gegenseitig hören, zu angemessenen Benennungen kommen. Diese Art der Seelsorge gründet auf dem Vertrauen, dass nicht die Seelsorgerin das Heil bringen muss oder könnte, sondern dass der Geist Gottes bereits in jeder Frau wohnt, dass sie als Frau bereits von Gott angenommen ist, eine Schöpfung Gottes, die die Seelsorgerin voll Achtung zu eigenem Sprechen hört.

\subsection{Hearing to speech als Kategorie der Befreiung und gesellschaftlichen Veränderung}

Das hearing to speech ist ein Prozess: gegenseitiger Ermächtigung und Befreiung von Frauen. In der Befreiung von Frauen verändert es gesellschaftliche Strukturen. "Hearing in this sense can break through political and social structures and image a new system" (Morton 1985:128). Es ist ein "gefährliches" Hören, wie es analog der Metz'schen Begriffe der gefährlichen Erinnerung und Erzählung genannt werden könnte, denn es bringt die verborgenen Leiden, die Sehnsüchte und Hoffnungen zum Ausdruck und schafft eine neue Sprache. "In time I came to understand the wider implication of this reversal as revolutionary and profoundly theological. Hearing of this sort is equivalent to empowerment. We empower one another by hearing the other to speech. We empower the disinherited, the outsider, as we are able to hear them name in their own way their own oppression and suffering" (Morton 1985:128). Die Ermächtigung ist ein wechselseitiger Prozess. Die Unterdrückten werden ermächtigt und ermächtigen sich gegenseitig, indem sie zur Artikulierung ihrer eigenen Sprache, ihrer Lebensgeschichte, zu ihrer "gefährlichen Erinnerung und Erzählung" gehört werden. "In turn, we are empowered as we can put ourselves in position to be heard by the disinherited (in this case other women) to speaking our own feeling of being caught and trapped" (Morton 1985:128). Auch diejenigen, die auf der Seite der Herrschenden stehen, könnten in diesem Prozess ermächtigt werden, ihre Rollen als die Mächtigen, die besseren Menschen, als die Wissenden, als Besitzende der Botschaft, als die Siegreichen 
abzulegen; sie könnten von den Unterdrückten gehört und ermächtigt werden, ihrer eigenen innersten Humanität, ihren eigenen Verletzungen, aber auch ihrer Schuld Raum und Ausdruck zu geben.

Ist aber ein solches hearing to speech auch zwischen Frauen und Männern möglich? Setzt es nicht symmetrische Beziehungen voraus, die in den gegenwärtigen patriarchalischen Strukturen nicht gegeben sind? Ein Weg echter Reziprozität zwischen Frauen und Männern kann in der Situation des Patriarchats nicht als selbstverständlich gehbar, nicht einmal als bekannt vorausgesetzt werden. Morton sieht in der Wechselseitigkeit eine Zukunftsvision, die aber bereits begonnen hat. Durch die Antizipation der Zukunft beginnt sich die gesellschaftliche Situation zu ändern.

We are safe to begin with mutuality in which both men and women can come into the process hearing and speaking openly with one another. Perhaps by the time women begin to be truly liberated, men can begin to hear women speak their speech and define their own needs. But the process itself anticipates the crumbling of the patriarchal system now experienced as sexism. Mutuality invites a totally new way that cannot now be described but can only be anticipated ...

(Morton 1985:84)

Der Grund für die antizipierende Hoffnung ist Gott, die/der die Schöpfung und die Menschen zu einem neuen befreiten Sprechen und Handeln hört. "A great ear at the heart of the universe - at the heart of our common life - hearing human beings to speech - to our own speech" (Morton 1985:128).

\subsection{Eine Theologie aus den Beziehungen zwischen Frauen}

Das hearing to speech ist im Beziehungsgeschehen zwischen Frauen entdeckt worden. "It traffics in another and different logic. It appears to belong in woman experience ..." (Morton 1985:128). Den Raum der Selbsterkenntnis als Frauen und der Artikulierung einer neuen, den eigenen Erfahrungen adäquaten Sprache können sich nur Frauen untereinander erschließen. So schreiben die Frauen der Mailänder Gruppe Libreria delle donne di Milano (1989: 60): "Der Mann stellt eine 
Verbindung her zwischen dir und der ganzen Welt, das ist richtig - aber nicht zwischen dir und dir selbst. Das kann dagegen die andere Frau ..." Die theologischen Reflexionen und Erkenntnisse aus diesen Erfahrungen bleiben zunächst an das Beziehungsgeschehen zwischen Frauen rückgebunden. Sie können nicht ohne weiteres verallgemeinert werden und auf eine Beziehung zwischen Männern oder zwischen Männern und Frauen übertragen werden; sie können auch nicht als universal-theologische Kategorien gelten.

Obwohl sich die Beziehung zwischen Frauen als eine Kategorie der Befreiung von Frauen erwiesen hat, gibt es keinen Begriff für sie. Sie ist unsichtbar, weil die Frau in Beziehung zum Mann oder in Richtung auf den Mann hin gedacht und durch den Mann oder über den Mann definiert wird. Die Frauen von Libreria delle donne di Milano haben der Beziehung zwischen Frauen den Namen "affidamento" gegeben, und dieser Name wurde in der Frauenbewegung rezipiert. "Der Name 'affidamento' ist schön, er trägt in sich die Wurzel von Wörtern wie fede (Glaube), fedeltà (Treue), fidarsi (vertrauen), confidare (anvertrauen)" (Liberia delle donne di Milano 1989:20). In der Bibel sehen sie ein solche Beziehung in der Geschichte von Ruth und Noemi erzählt. In der Beziehung zwischen Frauen kann die Erfahrung von Frauen ihren Ausdruck finden. "Eine Beziehung des affidamento eingehen heißt nicht, sich als Gleiche in der anderen zu spiegeln, um uns als die bestätigen zu lassen, die wir schon sind, es heißt, der menschlichen Erfahrung der Frau eine Möglichkeit geben, sich zum Ausdruck zu bringen und so in der Welt ihre wahre und große Existenz zu finden" (Libreria delle donne de Milano 1989:182).

\subsection{Die Frage nach einer "ganzen" Theologie}

Wenn die theologische Reflexion und Erkenntnis an die Beziehung unter Frauen gebunden bleibt, wie ist dann eine "ganze" - eine vollständige und eine gemeinsame Theologie möglich? Da Männer die Frauen aus den offiziellen und rituellen Funktionen der Kirche verdrängt haben, so schreibt Morton, und ihre heilenden und fürsorglichen Betätigungen durch das WORT, das Männer predigten, unterbrochen wurden, kann über eine ganze Theologie nur spekuliert 
oder phantasiert werden (vgl Morton 1985:83). Morton sieht eine solche Theologie nur in der eschatologischen Zukunft, deren Vision allerdings jetzt schon als Weg auf diese Zukunft hin antizipiert werden kann. Eine solche Theologie kann weder nur von Männern noch nur von Frauen kommen. Sie muss in einem Prozess entstehen, an dem Frauen und Männer gleichermaßen beteiligt sind. "Women cannot speak for the whole any more than men have been able to speak for the whole. A whole theology would envision all of the people speaking out of their own experiences into the process and toward full humanness" (Morton 1985:83).

Diese eschatologische Vision findet Morton in der jüdisch-christlichen Geschichte tradiert, in der Vision des Friedens, der alle Menschen und das Universum umfasst, in der Vision des neuen Himmels und der neuen Erde und in der Vision des kommenden Messias: "Messianic passages of the Biblical document desribed a coming one who would flesh out or fill out in wholeness that which the patriarchal community had rejected. They affirmed a future that would bring a new beginning of history when God's image (male and female) in humanity would be actual and apparent ... Doubtless there would be less Word of God and more speech of people" (Morton 1985:84). Die Menschen würden fähig, ihre heilende Verwandtschaft untereinander zu entdecken. Diese Vision ist nicht neu, sondern Teil unserer Glaubenstradition. Neu aber ist die Möglichkeit, dass sie jetzt mit aller Ernsthaftigkeit ergriffen wird und aus ihr gelebt wird, als wäre sie jetzt schon Wirklichkeit.

Wenn ich noch einmal dem philosophischen Gedankengang Adriana Cavareros folge und in Bezug auf die Suche nach einer ganzen Theologie weiterdenke, dann könnte eine ganze Theologie nur eine solche sein, in der Frauen und Männer ihre eigenen Erfahrungen und deren theologischen Reflexionen in der Form universalisieren und transzendieren, dass das Universale und Transzendente immer die ursprüngliche Differenz in sich trägt: Frauen könnten sich dann wirklich selbst universalisieren und sich als ein Spezifisches des Universalen wiedererkennen, und Männer würden sich selbst universalisieren und als ein Spezifisches des Universalen wiedererkennen, aber beide würden das Universale und das Transzendente als das Ganze einer 
ursprünglichen Differenz begreifen. Kein Geschlecht könnte sich mehr in Abwesenheit des anderen Geschlechts universalisieren. Jeder Erkenntnisprozess trägt das Geschlecht des oder der Erkennenden in sich.

Ein besonderes Problem entsteht, wenn das Universale, das Göttliche personal gedacht wird, wie dies in den Bildern der Bibel häufig geschieht und für den Glauben vieler Menschen sehr wichtig ist. Doch im priesterschriftlichen Schöpfungsbericht, der programmatisch an den Beginn der Schriften gestellt worden ist und in dem sich zum ersten Mal zeigt, wer Gott und die Menschen sind, scheint im personalen Gott die primäre Differenz der Geschlechter auf. „Dann sprach Gott: Lasst uns Menschen machen als unser Abbild nach unserer Gestalt ... Gott also schuf den Menschen als sein/ihr Abbild, als Mann und Frau erschuf Gott sie" (Gen 1:26f). Wenn Mann und Frau zugleich Ab-Bild Gottes sind, dann ist auch im Bild Gottes die primäre Differenz vorhanden (contra Cavarero 1993:88-92).

\section{PROBLEMFELDER EINER FEMINISTISCHEN PRAKTISCHEN THEOLOGIE - EINE SCHLUßBETRACHTUNG}

Feministische Praktische Theologie steht vor einer doppelten Problemstellung: Sie möchte einerseits methodisch reflektiert Erfahrungen von Frauen, ihre Benennungen und Reflexionen aufgreifen und sichtbar machen und in den theologischen Diskurs einbringen, und zum anderen Handlungsmodelle sichtbar machen oder entwickeln, die den Glauben und die befreiende Praxis von Frauen unterstützen. Die Frage des Zugangs zu Erfahrungen und zur Praxis von Frauen hat erkenntnis- und wissenschaftstheoretische sowie methodologische Implikationen, deren Diskussion teilweise noch aussteht. Zugleich ist aber der Blick in die Praxis der Frauen erhellend. Die Frauen in der Praxis haben ganz elementare Wege gefunden, um ihren eigenen Erfahrungen auf die Spur zu kommen, sie zu benennen und zu reflektieren. Die Methoden dieser Frauen sind für den praktisch-theologischen Diskurs aufschlussreich. So hat Nelle Morton einen Weg beschrieben, wie eine bislang unsichtbare Praxis von Frauen durch 
die Beschreibung und Benennung sichtbar und reflektierbar wurde und in der theologischen Reflexion neue theologische Theorien aus der Erfahrung von Frauen hervorbrachte. Morton beansprucht keine Allgemeingültigkeit für ihre Entdeckungen, doch haben sie sich im Laufe der Jahre immer wieder bestätigt und haben auch keinen direkten Widerspruch von anderen Frauen erfahren.

Die von Frauen in der Praxis entwickelten Methoden der Erfahrungserschließung können gewinnbringend auch für die wissenschaftliche Frage nach den Erfahrungen von Frauen sein. Zugleich können wissen-schaftliche Methoden der Praxis- und Erfahrungsgewinnung auf ihre Anschlussfähigkeit an die Wege der Frauen in der Praxis hin befragt werden. Sie können dazu beitragen, die Erfahrungen von Frauen zu erschließen und sichtbar zu machen. Von da her bieten sich Methoden an, die Raum geben für die selbststrukturierte Erinnerung und Erzählung von Erfahrungen. Die Biographieforschung, vor allem die Erzählanalyse und das Narrative Interview (vgl Klein 1994), die Oral History (vgl Niethammer 1985), die Erinnerungsarbeit (vgl Haug 1990) und andere Methoden (zur feministischen Methodendiskussion vgl Franke et al 2002; Diezinger 1994; Becker-Schmidt \& Bilden 1995:25-30; Mies 1978:41-63) weisen in diese Richtung. In diesem Zusammenhang wäre die konstitutive Rolle von Frauen als Forscherinnen für die Erschließung, Benennung und Reflexion von Erfahrungen von Frauen, die Bedeutung des hearing to speech - des Hörens als Ermächtigung von Frauen zum eigenen Sprechen - und des affidamento - der lebendigen Beziehung zwischen den Frauen - zu reflektieren.

\section{Literatur}

Becker-Schmidt, R \& Bilden, H 1995. Impulse für die qualitative Sozialforschung aus der Frauenforschung, in Flick, $\mathrm{U}$ et al $(\mathrm{Hg})$, Handbuch qualitative Sozialforschung: Grundlagen, Konzepte, Methoden und Anwendungen, 23-30. Weinheim: Beltz, Psychologie-Verlags Union.

Belenky, M F et al 1989. Das andere Denken, Persönlichkeit, Moral und Intellekt der Frau. Frankfurt/Main, New York: Campus.

Brown, L M \& Gilligan, C 1994. Die verlorene Stimme: Wendepunkte in der Entwicklung von Mädchen und Frauen. Frankfurt/Main, New York: Campus. 
Cavarero, A 1993. Ansätze zu einer Theorie der Geschlechterdifferenz, in Diotima: Philosophinnengruppe aus Verona, Der Mensch ist zwei: Das Denken der Geschlechterdifferenz, 65-102. Wien: Wiener Frauenverlag.

Diezinger, A $(\mathrm{Hg})$ et al 1994. Erfahrung mit Methode: Wege sozialwissenschaftlicher Frauenforschung. Freiburg: Kore.

Franke, E et al 2002. Frauen Leben Religion. Ein Handbuch empirischer Forschungsmethoden. Stuttgart, Berlin, Köln: Kohlhammer.

Haug, F 1990. Erinnerungsarbeit. Hamburg: Argument.

Kaempfert, M (Hg) 1983. Probleme der religiösen Sprache, Darmstadt: Wissenschaftliche Buchgesellschaft.

Klein, S 1994. Theologie und empirische Biographieforschung: Methodische Zugänge zur Lebens- und Glaubensgeschichte und ihre Bedeutung für eine erfahrungsbezogene Theologie, Stuttgart, Berlin, Köln: Kohlhammer.

Klein, S 1997. Hören als Ermächtigung zum Sprechen (Hearing to Speech): Zur Entdeckung einer theologischen Kategorie. Pastoraltheologische Informationen 17, 283-297.

Knauer, P 1983. Der Glaube kommt vom Hören: Ökumenische Fundamentaltheologie. Bamberg: Schadel.

Libreria delle donne di Milano 1989. Wie weibliche Freiheit entsteht: Eine neue politische Praxis. Berlin: Orlanda-Frauenverlag.

Luther, $\mathrm{H}$ 1987. Der fiktive Andere - Mutmaßungen über das Religiöse an Biographie, in Grözinger, A \& Luther, H, Religion und Biographie: Perspektiven zur gelebten Religion, 67-78. München: Kaiser.

Metz, J B 1973. Kleine Apologie des Erzählens. Concilium 9, 334-341.

Metz, J B 1977. Glaube in Geschichte und Gesellschaft. Mainz: Grünewald.

Mies, M 1978. Methodische Postulate zur Frauenforschung. München: Frauenoffensive (Beiträge zur Feministische Theorie und Praxis 1.)

Morton, N 1985. The journey is home. Boston: Beacon Press.

Niethammer, L (Hg.) 1985. Lebenserfahrung und kollektives Gedächtnis: Die Praxis der „Oral History”. Frankfurt/Main: Suhrkamp.

Pusch, L F 1984. Das Deutsche als Männersprache: Aufsätze und Glossen zur feministischen Linguistik. Frankfurt/Main: Suhrkamp.

Pusch, L F 1990. Alle Menschen werden Schwestern. Frankfurt/Main: Suhrkamp. Schüssler Fiorenza, E 1985. Das Schweigen brechen - sichtbar werden. Concilium 21, 387-398.

Streib, H 1996. Heilsames Erzählen: Pastoraltheologische und pastoralpsychologische Perspektiven zur Begründung und Gestaltung der Seelsorge. Wege zum Menschen 48, 339-359. 
Trömel-Plötz, S 1982. Frauensprache - Sprache der Veränderung. Frankfurt/Main: Fischer.

Trömel-Plötz, S (Hg) 1984. Gewalt durch Sprache: Die Vergewaltigung von Frauen in Gesprächen. Frankfurt: Fischer.

Trömel-Plötz, S 1993. Vatersprache Mutterland: Beobachtungen zu Sprache und Politik. München: Frauenoffensive.

Weinrich, H 1973. Narrative Theologie. Concilium 9, 329-334. 